\title{
The Correlation between Health Care and the Purple Economy its Impact on Sustainable Development in Egypt

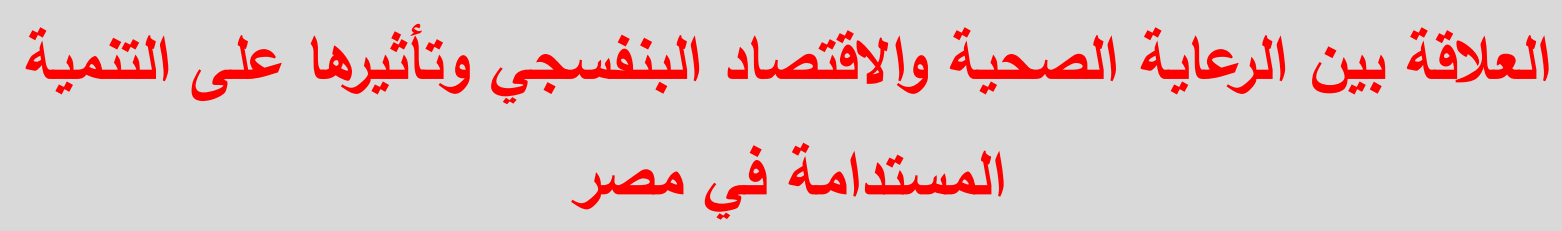

DR. Hend Morsy Mohmed Ali Al Brbrby

Economics teacher - Faculty of Politics and Economics

Beni Suef University

\section{$\underline{\text { Abstract: }}$}

This research aims to study and analyze the relationship between health care, purple economy, and the extent of the impact of that relationship on sustainable development in its three dimension, economic, environmental, and social, with the aim of reaching the extent and direction of the relationship between the prevailing culture in Egyptian society, relationship to health care, and its impact on indicators of sustainable development in Egypt. Using the descriptive method and the standard analysis approach.

The researcher proved that there is no clear moral relationship between health care, purple economy in Egypt, and a negative, non-moral relationship between health care. it is proved that sustainable development found, as well as a negative and non-moral relationship between the purple economy and sustainable development in Egypt. This means the necessity of making greater efforts to promote health care and develop in Egypt to achieve targeted sustainable development rates.

Keywords: Healthcare - purple economy - sustainable development.

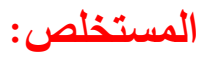

يهدف البحث إلى دراسة وتحليل العلاقة بين الرعاية الصحية والاقتصاد البنفسي ومدى ثأثنر تلك

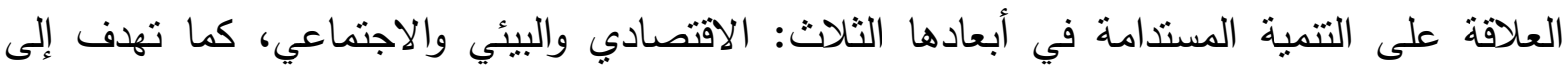

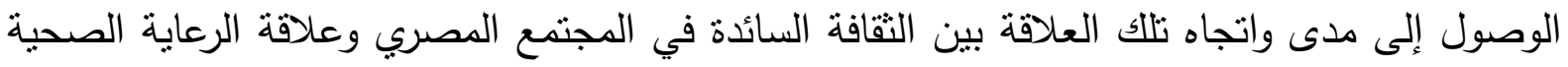
وتأثرها على مؤشرات التتمية المستدامة عن طريق استخدام المنهج الوصفي واقتتراب التحليل القياسي. 


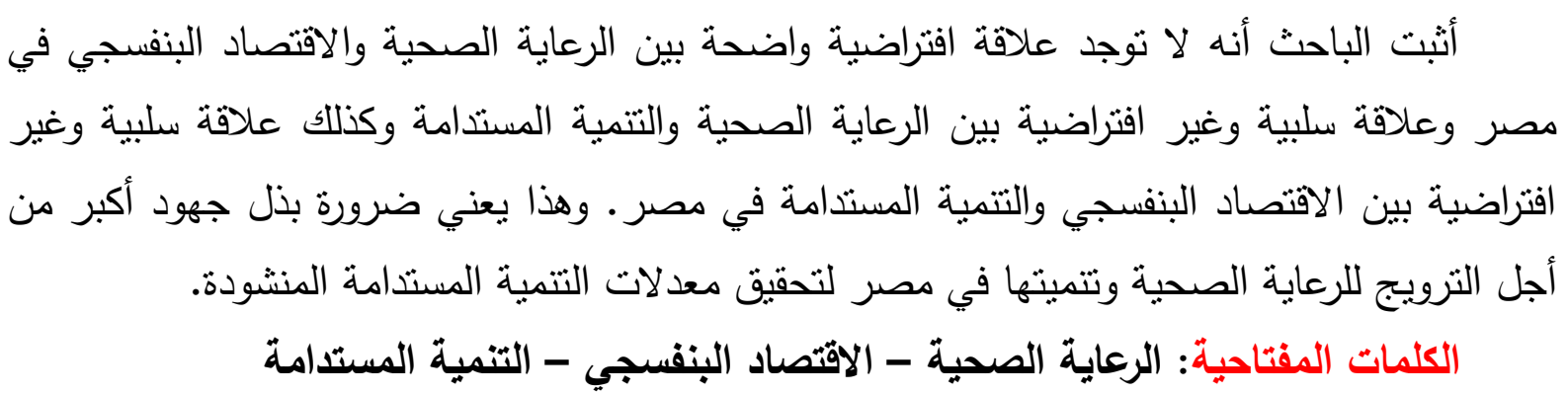

\section{1- Introduction:}

Growth rates varied in 2004 and formed in 2010. Environment in addition to the cultural dimension- which has become the decisive factor in facing this epidemic-are the countries that were able to emerge from the crisis with less losses.

The purple economy adds a new dimension to economic development, which are the human and cultural dimension, including the values it contains related to the culture of society, in a way that makes culture a servant of economics and achieves its goals. This branch of economy represents one of the components of sustainable development, which consists of the green economy that relates to the natural environment and the social economy related to the environment. social, in addition to the purple economy, which is related to the cultural dimension.

Egypt suffers from a decrease in the efficiency of the health care sector, which causes a highest death rate in health care sector in the world despite the low rates of disease compared to other countries in the region such as Iran and Turkey, for example.

This research paper aims to determine the causal relationship between health care services and its relationship to the purple economy and the impact of that relationship on sustainable development in Egypt through:

- Healthcare services concept and policies followed in Egypt.

- The concept of the purple economy and its relationship to sustainable health development.

- Indicators of health care services in Egypt and their relationship to the purple economy and sustainable development.

1/1- Research problem: Egypt suffers from poor health care services due to lack of funding and investments in this field, in addition to the spread of the phenomenon of emigration of doctors and medical personnel due to the combination of economic factors (such as low health allocations and public spending on the medical sector) and cultural factors such as customs, traditions, religious ideas, level of education and general culture. This has exacerbated the 
health crises, especially with the outbreak of the Covid 19 epidemic, which raised the infection and death rates, especially among medical staff.

1/ 2- The research hypotheses: The research seeks to ascertain the validity of the following hypotheses

1- There is a strong causal relationship between general culture, health culture and health care.

2- Weak government spending on the health sector weakened the material and human capabilities in this sector. Which threatens economic and social stability, weak productivity and development.

3- Social, economic, environmental and cultural factors affect the health care sector and sustainable development.

1-3 Research objectives: The research aims to shed light on the following missteps:

$>$ Defining the concept of health care and getting to know the policies followed in Egypt for the advancement of this sector.

$>$ Determine the relationship between health care and the purple economy (cultural factors)

$>$ Defining the relationship between health care and sustainable development in its economic, environmental, social and cultural dimensions.

1 / 4- Research methodology: The research relies on the descriptive analysis and the standard analysis approach to analyze data and variables affecting the health sector and its relationship to the purple economy and the impact of that relationship on sustainable development in Egypt.

1/5 Research boundaries: The relationship between the independent and dependent variables in Egypt during the period from 2000 to 202 is analyzed.

2- Previous studies: There are many previous studies that dealt with studying the relationship between healthcare and sustainable development, including:

1. Bo Maraf, E \& Amari, A (2009). ${ }^{194}$ They analyzed the reality of health in Algeria and its relationship to sustainable development, the obstacles that stand in the way of achieving the goals of this development, and ways to make health sustainable in Algeria. They concluded that the process of promoting, sustaining healthy development requires improving the economic, social, and environmental conditions that affect the lives of individuals.

2. Mazrak, S \& Mebrouk, B (2013). ${ }^{195}$ This study aims to identify the dimension, quality health services, the related concepts, to define the concept of sustainable development, its various dimension, and the role that improving the quality of health services plays in supporting the dimension of sustainable development. The study reached many general theoretical results and the practical results on the institution under analysis.it is represented in 
the fact that healthcare services are affected by the awareness of service providers, and technical progress in the medical sciences in addition to the human aspect.

3. Al-Fatih, M O M (2013). ${ }^{196}$ The researcher described and analyzed healthcare services in developing countries and their effects on development, explaining the concept of health care services, the importance of health care economics and health policies, and the impact of health care economics on developing countries. The researcher concluded the need to provide appropriate means for the healthcare sector that contribute to providing that care for all Citizens so that development can be achieved, in addition to qualifying, training, and motivating medical personnel to stop their migration to developed countries.

4. Mukhtar, R (2014). ${ }^{197}$ The research aims to study the relationship between health, disease, and the cultural coordination of society. The researcher has concluded that there is a close relationship between health, disease, the cultural, social coordination of society, and this scientific aspect falls on the responsibility of anthropology to study this relationship.

5. Jennifer $\mathbf{R} \&$ others (2016). ${ }^{198}$ They presented an investigation of the relationship between social spending and health outcomes at the sub-national level (i.e., within the United States of America). The target audiences for this field study were policy- makers, practitioners, and other interest groups aimed at assessing healthcare reforms, outcomes, broader social outcomes, as well as researchers and policy specialists who focus on social protection systems and public health. The study found that the United States achieved poor results in population health compared to other member countries of the Organization for Economic Cooperation and Development. Although the average per capita social spending is higher in the United States compared to those countries.

6. Ana, S F \& others (2017). ${ }^{199}$ They examined the relationship between the purple economy and the economics of care, sustainable development. The study focused on researching the economics of homecare and relying on attracting domestic workers from the developing world to take care of children and the elderly and carry out daily household chores in the West. And its impact on home care in developed and developing countries.

7. Santosh \& Snehlata (2018). ${ }^{200}$ They examined the extent of the purple economy being one of the components of sustainable economic development in India, they concluded that the purple economy is multidisciplinary because it is included in all goods and services because the cultural dimension is inherent in all sectors and therefore the purple economy is part of the growth context. Culture has importance in contemporary society, which is characterized by globalization, as it allows economic and political adjustment 
in favor of developing countries, a return to the local environment and new forms of demand in proportion to cultural consumption patterns, and the purple economy in that part of sustainable development that enhances the cultural potential of goods and services, which takes into account the cultural aspects of the economy that adapts to human diversity in the light of globalization. Where they emphasized the contribution of the purple economy to sustainable development. They found that cultural economy has more prospects in that it represents a potential for growth that depends on largely immaterial foundations.

8. Al-Jabouri, A N (2019). ${ }^{201}$ The researcher aims to identify the concept of health care sustainability, the factors that help to achieve sustainable development and future trends in this field. The researcher concluded that the sustainability movement in the field of healthcare should be accelerated and the way to this acceleration is efficient planning and design.

From the foregoing, we note that most of the previous studies discuss the relationship between health care, health economics, sustainable development, no one has addressed the issue of the purple economy, its closeness to healthcare and the impact of cultural factors on healthcare valuation and its impact on sustainable development. This paper studies the reciprocal relationship between healthcare, the purple economy, and the effect of that relationship on sustainable development in Egypt.

\section{4- Healthcare services concept and policies followed in Egypt:}

\section{4/1 Concept of Healthcare Services:}

Healthcare is the group of public, private services, and institutions that the state provides with the aim of taking care for the health of its citizens, whether in governmental or private sector institutions that are concerned with treating patients and include hospitals, clinics, pharmacies. human resources of doctors and nurses and everyone working in this field, and industries related to health services, such as the manufacture of medicines, medical devices compensation, medical research, and education services. The state works to create opportunities for successive generations to obtain sustainable health care through policies that support this sector.

Health care economics is one of the modern branches of economics that research how to apply economics tools to health issues, to become more analytical. And economics provides the criteria that determine the effectiveness of health policies in achieving economic efficiency and equitable distribution of health care services.

The means of obtaining health care differ in different individuals, societies, countries, affected by social, economic, cultural, health policies adopted in the country, the policies, plans, goals of personal and population health care in different societies. 
There are many factors affecting health care, explained by Dilgren and Whitehead (1993) ${ }^{202}$ in Figure (1), where social factors (economic, cultural, environmental) affect local community networks and social networks, which in turn affect living conditions, working conditions, education, living, housing, health care and water use, sanitation, agriculture, and food production. What influences an individual's lifestyle, age, gender, and consequently affects and is affected by it.

Figure No. (1) Factors affecting health care.

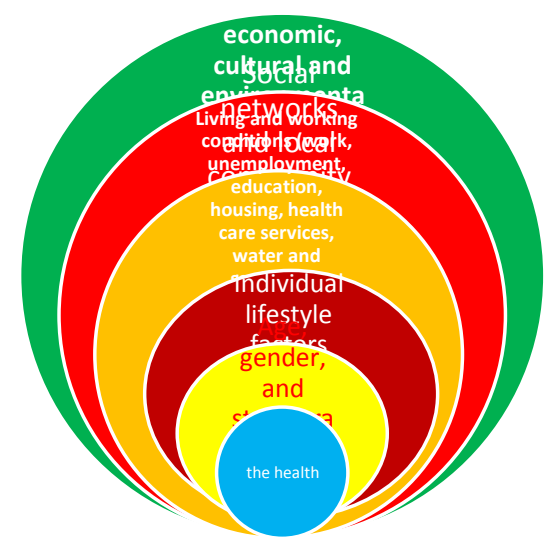

Source: Adapted from the researcher. Adapted from degree \& Whitehead 1993. From the report of the WISH Forum on Healthy Communities 2016. p. 7.

\section{3- Health Care Objectives:}

Healthcare aims to provide high-quality medical resources to all who need it to ensure quality of life, treat diseases where possible, increase life expectancy and other goals of that care. The National Academy of Medicine in the United States of America has launched six scopes to measure, describe the quality of safe health care to avoid injury to patients, and these points are: ${ }^{203}$

1. Effectiveness: avoid over-caring or abuse.

2. Patient focus: Provide care specific to the patient's needs.

3. On appointment: Reducing waiting time and delays that are harmful to patients and caregivers.

4. Efficiency: Avoid wasting equipment, supplies, ideas, and energy.

5. Equity: Providing care in such a way that it does not differ according to the essential personal characteristics.

\section{4 - Health care stages:}

There are many stages of health care between primary, secondary, tertiary and quadruple care, which are different stages of health care, each with its own cultural, economic, and social requirements and can be classified into: ${ }^{204}$

Primary care: refers to those who work in primary consultations for all patients within the health care system, such as a general practitioner or a family doctor, according to the health system in Egypt. Primary care can be provided in 
community health centers. Primary care is the first element in the continuing health care process and may also include the provision of secondary and tertiary care levels. Primary care consists of health education, environmental health, health programs for child and mother care, vaccination and family planning, prevention of endemic diseases, appropriate treatment of common diseases and injuries, and provision of the necessary medicines, spread awareness of the foundations of healthy nutrition, traditional treatment methods.

\section{Figure No. (2) Primary health care components}

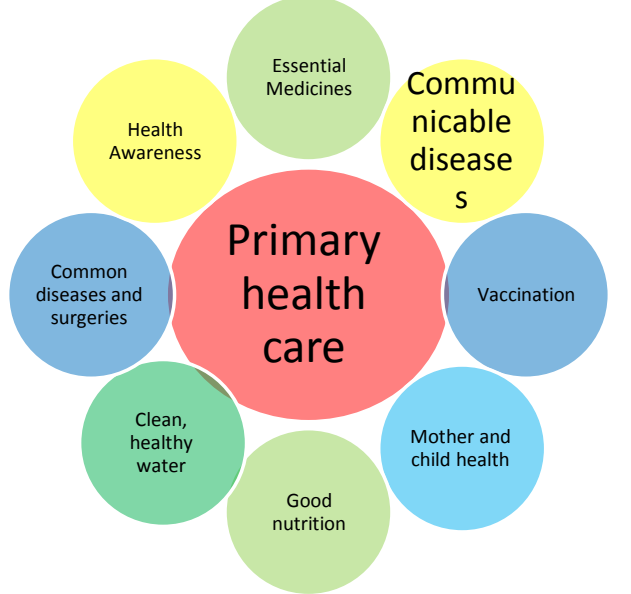

Source: https.wikimedia.org

Secondary care: The term "secondary care" is used as a synonym for hospital care.

Triple care: is a specialized health care advisory, in a facility that has personnel and facilities for an advanced and specialized medical examination.

Quadruple care: The term quaternary care is sometimes used as an extension of tertiary care to refer to advanced levels of highly specialized medicine that are not widely accessible.

All stages of health care need health education, whether for health workers or for health service recipients. However, the primary care stage is the most important stage in which work must be done to develop and qualify its employees to be able to provide health care services in a manner appropriate to different cultures.

\section{5- Health care policies in Egypt:}

The health care sector in Egypt faces many challenges, including increasing the total fertility rate to reach 3.5 children per woman in 2018, from 2.9 in 1990. In addition, Egypt ranked first in the world in 2015 in infection with hepatitis virus (C), where 5\% of the adult population in Egypt was infected with this disease. The incidence of non-communicable diseases (such as high blood pressure, obesity, and diabetes) is also increasing, as the death rate from these diseases reached $82 \%$ of the total deaths and about $67 \%$ of premature 
deaths. Levels of primary health care facilities are low in public hospitals, prompting about $60 \%$ of patients to seek health care in private clinics and hospitals, which incur high costs for patients. As a result of these problems, the Egyptian government requested the support of the World Bank to support an initiative aimed at implementing a new system to ensure stones to provide and improve the quality of comprehensive health care. Accordingly, the 100 Million Health Project was prepared, which was designed to achieve the goals of Egypt's 2030 vision for sustainable development to achieve comprehensive health development. ${ }^{205}$

The sustainable development strategy for Egypt Vision 2030 in the field of health aims for Egyptians to enjoy a healthy and safe life through the application of an integrated health system characterized by availability, quality and non-discrimination, and capable of improving health indicators by achieving comprehensive coverage for all citizens in a way that achieve financial protection for the incapable and achieve satisfaction Citizens and workers in the health sector to achieve prosperity and well-being, what makes Egypt a pioneer in this field at the Arab and African level. The strategic vision for health in Egypt is crystallized in achieving three main goals until 2030, as shown in the following table:

Table No. (1) goals of the sustainable development strategy Egypt Vision 2030 in the field of health

\begin{tabular}{|l|l|}
\hline \multicolumn{1}{|c|}{ Target } & \multicolumn{1}{|c|}{ the definition } \\
\hline $\begin{array}{l}\text { Promote citizens' health } \\
\text { in a framework of justice } \\
\text { and equity. }\end{array}$ & $\begin{array}{l}\text { Attention to everything that affects the health of } \\
\text { Egyptians in terms of social determinants, } \\
\text { infrastructure, and public awareness, and stimulating a } \\
\text { healthy lifestyle. }\end{array}$ \\
\hline $\begin{array}{l}\text { Achieving universal } \\
\text { health coverage for all } \\
\begin{array}{l}\text { Egyptians while ensuring } \\
\text { the quality of services } \\
\text { provided }\end{array}\end{array}$ & $\begin{array}{l}\text { Attention to providing high-quality curative and } \\
\text { preventive services available to all able and } \\
\text { disadvantaged Egyptians }\end{array}$ \\
\hline Health sector governance & $\begin{array}{l}\text { Availability of accurate data that leads to sound } \\
\text { decisions in a timely manner while improving the } \\
\text { efficiency of managing health sector resources in a } \\
\text { framework of transparency and accountability. }\end{array}$ \\
\hline
\end{tabular}

Source: Egypt Vision 2030 - Egyptian Ministry of Planning - pg. 137

To achieve these strategic goals, the World Bank-supported healthcare project for Egyptians was implemented in 2018 to serve 55 million citizens to improve the services of 600 primary health care facilities, 27 hospitals. strengthening family planning efforts, expanding the range of rural female health leaders, examining one million blood units annually to ensure that blood 
bags are free of infection, and launching the 100 Million Health Initiative aimed at eliminating virus $\mathrm{C}$ and detecting non-communicable diseases. ${ }^{206}$

The initiative has achieved good results, as a complete survey of 27 governorates across the country has been completed. 55 million adult citizens (over 18 years old) were examined, Virus $\mathrm{C}$ was detected for about 3.2 million middle school and high school students, 13 million students were examined for malnutrition, stunting and obesity, and 24 thousand foreigners who attended the initiative and received health services were examined. The number of $\mathrm{BCr}$ testers for the presence of antibodies to the $\mathrm{C}$ virus in their blood reached 2.8 million, and 2.2 million citizens carrying the disease were discovered, and treatment was dispensed to them and periodic examination is underway, but full cure rates have not been counted until now. Waiting lists for operations in government and private hospitals nationwide have also been reduced by $68 \%$, as 283,000 operations were received from waiting lists until the end of $2019 .{ }^{207}$

5- The concept of the purple economy and its relationship to sustainable development:

There is a reciprocal relationship between the purple economy, sustainable health development and the dimensions of development. To identify that relationship, we will first define the concept of the purple economy, and then its relationship to health care and sustainable development as follows.

\section{1- The Purple Economy Concept:}

Psychological economics one of the most recent branch of economics, a branch of economics that emphasizes the need to humanize globalization use culture to contribute to achieve sustainable development dimensions, as the cultural return of good and services are valued. And the purple economy carries with it values related to the culture of society. Achieve the human response and interaction with the surrounding environment. Thus, culture will serve the economy and connect to its goals. And the purple economy includes within its framework the cultural environment in which agents leave their mark and which remains a common global property. In this context, the purple economy makes the cultural dimension a pawn for sustainable development.

The emergence of the purple economy is due to the growing importance of the cultural aspect in contemporary society. And the purple economy is of a holistic nature in that it values all goods and services, regardless of their sectors, based on the cultural dimension. It was applied in sensory and experimental economics. It differs from the cultural economy, which is based on the logic of sectors. $^{208}$

The term "violet economy" first appeared in France in 2011 in a document published by "Le Monde" newspaper by the "Diver sum" association when it organized the first international forum on the purple economy, under the auspices of UNESCO, the European Parliament, and the European Commission. 
It is the first time that this relationship has been touched upon by the term purple economics. ${ }^{209}$

\section{2-The relationship between the purple economy and sustainable development:}

Cultural character is an important challenge to achieving sustainable development. Corporate social responsibility also derives from the International Covenant on Economic, Social and Cultural Rights adopted by the United Nations in 1966. Cultural factors represent only one component of sustainable development, along with factors related to the natural environment (green economy), and those related to the social environment (social economy). The complementarity of aspects of the sustainable economy was emphasized by a call published by Le Monde Economy in 2015 at the 21st United Nations Climate Change Conference.

UNESCO considers culture to be the founding element of our identity. Establishing culture at the core of development policies is the only way to achieve human-centered development that is comprehensive and equitable, and culture was included for the first time in the international sustainable development agenda, as part of the development goals adopted by the United Nations in September 2015. Where it was recognized that protecting culture its development is an end and a means of directly contributing to the achievement of many of the Sustainable Development Goals.

Safe and durable cities, decent work, and economic growth, narrowing social class gaps, and gender equality create peaceful and inclusive societies. Also, working with development goals leads to reaping indirect benefits culture. $^{210}$

The Purple Economy is one of the three components of a sustainable economy, namely the social, environmental, and cultural (Purple) economy.

Figure No. (3) the three dimensions of sustainable economic development

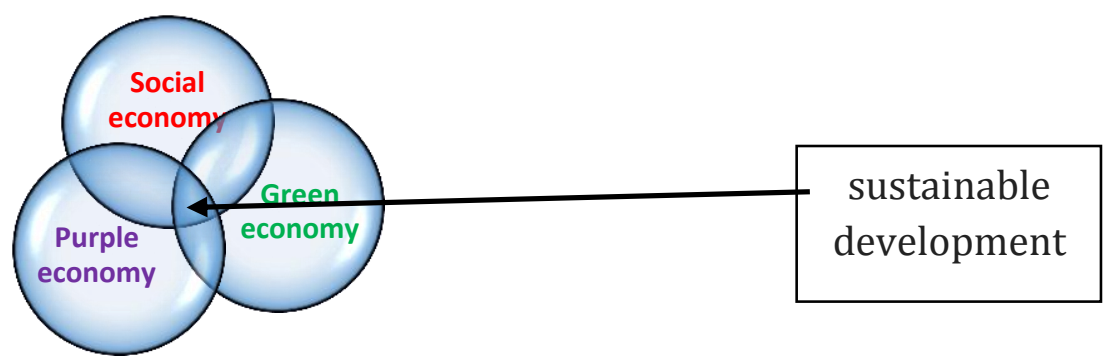

Source. At the disposal of the researcher

The purple economy comes to consolidate the issue of corporate social responsibility, which derives its roots from the International Charter on Economic, Social and Cultural Rights adopted by the United Nations in 1966.

\section{3 - The relationship between health care and culture:}


Health culture can be defined as a set of methods, and organized awareness-raising measures directed at community members, to form a supportive influence force that increases positive societal perceptions of health issues and practices, and changes ideas and false information adopted by some, and these ideas then turn into behaviors, which improves health conditions Societal in general. Numerous studies and academic researchers have found a strong relationship between health, disease, the cultural and social pattern in different societies.

Health education aims to introduce individuals to the concepts of health education, public health, to assist them in identifying diseases and finding a cure for health problems. And modifying the culture of individuals towards health is a reason for changing unhealthy behavior in treatment, which reduces disease rates and develops people's lives.

The elements of health education are the health message, the health message, the ones who are targeted by health education, and the means of health education. Where there are many means of health culture between the culture of individuals, resources, and educational methods. The importance of health culture is that it reduces the worsening health problems in the modern world, including the emergence of dangerous diseases, the ease with which infection spread (such as AIDS, Corona, SARS and others) in addition to the lifestyle that depends on comfort and luxury, the use of modern technology, how to recycle or dispose of waste accordingly. Preserves public health and environment. ${ }^{211}$

\section{6 - Research methodology:}

The research relies on the descriptive analysis method, the standard analysis to analyze data, variables affecting the health sector, its relationship to the purple economy and the impact of that relationship on sustainable development in Egypt.

regression model to test the relationship between sustainable development, health care, and culture in the Egyptian economy by using the econometric method to arrive at results through a set of steps: (1) Determine the model used. (2) Static variables testing using ADF test. (3) Multiple regression model estimation. (4) Test the quality of the model used.

We will use a multiple regression model to test the relationship between sustainable development as a dependent variable (expressed as the rate of economic growth (GDYt)) and its effect on health care as an independent variable expressed by life expectancy at birth (LIFt), and culture as another independent variable expressed in variables (the ratio of exports and imports to GDP, OPENt, Ratio of secondary school enrollment to total EDUt, inflation rate INFt, population growth rate (POPt), fixed capital formation ratio $\mathrm{FCt}$ )

\section{- Determine the model used:}


A Multi-regression model was used. And the variables that were used in the form of annual growth rates, or in the form of percentages, and the source of data for the variables from the reports of the World Bank, and the E Views program was used to obtain the results.

Model Equation Estimation:

GDPt $=$ at + EDUt + OPENt +LIFt +INFt + POPt + FCt + et

$$
t=1.2 .3 \ldots \ldots \ldots \ldots \ldots n
$$

As the time (t), the number of observations (n). and whereas:

The constant term.

(at)

The economic growth rates.

(GDPt)

Fixed capital formation rate.

Population growth rate.

Ratio of exports and imports to GDP.

(OPENt)

Inflation Rate.

(INFt)

The ratio of high schools' enrollment to total.

(EDUt)

Limits of random error.

Life expectancy at birth.

(LIFt)

\section{2- Static variables test:}

The first step after defining the model is to test the static of the variables in that model. There are many studies that test the Unit Root for each variable separately using the Augmented Dickey - Fuller (ADF) test. By conducting this test on the model variables, he confirmed that there is stillness for the variables used in the study at its original levels.

\section{3- Estimate the multiple regression model used:}

Before estimating the model, the quality of the multiple regression model must be tested statistically and stylistically, as diagnostic tests must be performed to identify the model's quality:

a) Lagrange Multiplier test of residual (Breush - Godfrey - BG)

b) Normality test.

c) Heteroscedasticity test.

As for these tests, Table (1 - 1) shows their results as follows:

Table (3) the results of the diagnostic tests for the multiple regression model

\begin{tabular}{|l|l|l|l|l|l|l|l|}
\hline $\begin{array}{l}\text { Null } \\
\text { hypothesis } \\
(H O)\end{array}$ & $\begin{array}{l}\text { Test } \\
\text { statis } \\
\text { tic }\end{array}$ & \multicolumn{5}{|c|}{ F statistic } \\
\hline & & OPE & LIF & INF & FC & POP & EDU \\
\hline
\end{tabular}




\begin{tabular}{|c|c|c|c|c|c|c|c|}
\hline & & $N$ & & & & & \\
\hline \multirow[t]{2}{*}{ No serial link } & \multirow[t]{2}{*}{$L L M$} & $\begin{array}{l}0.0163 \\
09\end{array}$ & 3.74 & $\begin{array}{l}- \\
0.00559 \\
1\end{array}$ & $\begin{array}{l}0.00340 \\
7\end{array}$ & 0.1300 & -0.0019 \\
\hline & & $\begin{array}{l}0.715 \\
6\end{array}$ & 0.8174 & 0.9132 & 0.9786 & 0.9473 & 0.9792 \\
\hline \multirow{2}{*}{$\begin{array}{l}\text { Stability of } \\
\text { the variance } \\
\text { of the } \\
\text { random error } \\
\text { limit }\end{array}$} & \multirow[t]{2}{*}{$\begin{array}{l}A R C \\
H\end{array}$} & 0.022 & -40.84 & $\begin{array}{l}0.00574 \\
3\end{array}$ & -0.080 & $\begin{array}{l}0.85270 \\
6\end{array}$ & $\begin{array}{l}0.14133 \\
7\end{array}$ \\
\hline & & $\begin{array}{l}(0.70 \\
5)\end{array}$ & (0.1038 & $(0.9412)$ & 0.6775 & 0.77 & $(0.2228)$ \\
\hline \multicolumn{4}{|c|}{$\begin{array}{l}\text { The normal distribution of random } \\
\text { errors }\end{array}$} & \multicolumn{4}{|c|}{\begin{tabular}{|l|} 
Test of \\
Jarque- bera (3.632) \\
Prob $(0.1626)$ \\
\end{tabular}} \\
\hline
\end{tabular}

source. results of the Standard Model. From the researcher's work

It is clear from Table (3) that the results of the diagnostic tests of the multiple regression model used, enable us to decide the validity of using the multiple regression model in estimating the relationship between health care and economic growth in the Egyptian economy, as the results of the tests indicate the following:

a) The LM statistic indicates that the model is free from the problem of serial correlation. This is evidence that the chosen slowdown period is indeed optimal. It is known that the optimum slowdown period that ensures that there is no self-correlation between the rest.

b) The ARCH test statistic denotes acceptance of the null hypothesis that the random error limit variance of Homoscedasticity is consistently accepted in all equations of the estimated model.

c) The JB test statistic denotes acceptance of the assumption that random errors are normally distributed in all equations of the estimated model.

To test whether there is a multicollinearity problem in the estimated model, the correlation coefficient between each of the two independent variables of this model was estimated. In general, there is an acute linear duplication problem if the value of the correlation coefficient between two independent variables within an equation is greater than 0.7 , and it is clear from the measurement results that the value of the correlation coefficient between each of the two independent variables did not exceed 0.7, and then there is no linear duplication problem in the model Estimated.

The value of the coefficient of determination (R2) indicates an increase in the explanatory power of the independent variables of interest. (0.56) The value 
of the F-statistic test indicates the quality of the overall estimated model statistically.

* Negative and insignificant effect of health care, expressed in life expectancy at birth, on economic growth, which means the need to pay more attention to health care that will lead to an increase in economic growth in Egypt.

* Presence of a negative and non-significant impact of the education and culture variable, which is represented in the number of enrollments in secondary schools out of the total, this reflects the importance of working to increase interest in human capital and culture.

* There is a positive and significant effect of the inflation rate on the economic growth in Egypt.

* The existence of a negative and insignificant effect on total exports and imports as a percentage of real GDP on the economic growth in Egypt, and this results from the increase in imports and the decrease in the export process.

* There is a positive and non-significant effect of the capital formation rate, and this means that we need to develop our financial and banking markets.

\section{5- Conclusion:}

This research assumes that there is a causal relationship between health care and the purple economy. This relationship has an impact on sustainable development in Egypt. The concept of health care and exposure to health care services in Egypt and its relationship to the purple economy (culture) were presented. The concept of the purple economy and its relationship to sustainable development was also recognized. To verify the relationship between the different variables, a regression analysis model was used to find out the strength, direction of the relationship between health care, the purple economy (culture) sustainable development in Egypt, and despite the efforts made by the state to pay attention to health care, it is still below the rates that affect sustainable development.

Where it was found that there is a negative (negative) and insignificant effect of health care on economic growth (as an indicator of sustainable development). There is also a negative (adverse) effect of culture on the rate of output growth in Egypt, which means that the Egyptian government must make a greater effort to pay attention to health care, culture, education to achieve greater growth rates and raise sustainable development rates.

The research recommends that we should work to increase public spending

on health, public health cultural development, and raise the level of health awareness among Egyptian citizens, so that we can raise the level of efficiency

of health care in Egypt, to ensure the achievement of the targeted sustainable 
development rates according to the 2030 plan for sustainable development in

Egypt, especially in Egypt. Healthcare sector.

6-Supplements are outputs E viws 9

Vector Autoregression Estimates Date: 07/22/20 Time: 14:01 Sample (adjusted): 1982 2017. Included observations: 30 after Adjustments. Standard errors in ( ) \& t-statistics in [ ]

\begin{tabular}{cc}
\hline \hline & GDP \\
\hline \hline GDP(-1) & -0.099723 \\
& $(0.18679)$ \\
GDP(-2) & $0.53387]$ \\
& 0.218455 \\
C & $(0.17082)$ \\
& {$[1.27888]$} \\
EDU & 72.46689 \\
& $(68.2431)$ \\
INF & {$[1.06189]$} \\
& -0.084343 \\
& $(0.07771)$ \\
LOG(LIF) & {$[-1.08533]$} \\
& 0.080661 \\
& $(0.07459)$ \\
POP & {$[1.08144]$} \\
& -12.47451 \\
OPEN & $(16.0820)$ \\
& {$[-0.77568]$} \\
FC & -5.114408 \\
& $(2.27913)$ \\
& {$[-2.24401]$} \\
& -0.080316 \\
& $(0.05683)$ \\
& {$[-1.41335]$} \\
& 0.180657 \\
& $(0.13714)$ \\
& $1.31730]$ \\
\hline \hline
\end{tabular}


R-squared

Adj. R-squared

Sum sq. resids

S.E. equation

F-statistic

Log likelihood

Akaike AIC

Schwarz SC

Mean dependent

S.D. dependent
0.561614

0.394609

48.85735

1.525300

3.362870

$-49.88377$

3.925584

4.345944

4.527880

1.960367

Breusch-Godfrey Serial Correlation LM Test:

\begin{tabular}{llll}
\hline \hline F-statistic & 0.661976 & $\begin{array}{l}\text { Prob. F(2,23) } \\
\text { Prob. Chi- }\end{array}$ & 0.5254 \\
& &
\end{tabular}

Obs*R-squared 1.741759Square(2)

0.4186

Test Equation:

Dependent Variable: RESID

Method: Least Squares

Date: 07/22/20 Time: 14:05

Sample: 19802017

Included observations: 32

Presample and interior missing value lagged residuals set to zero.

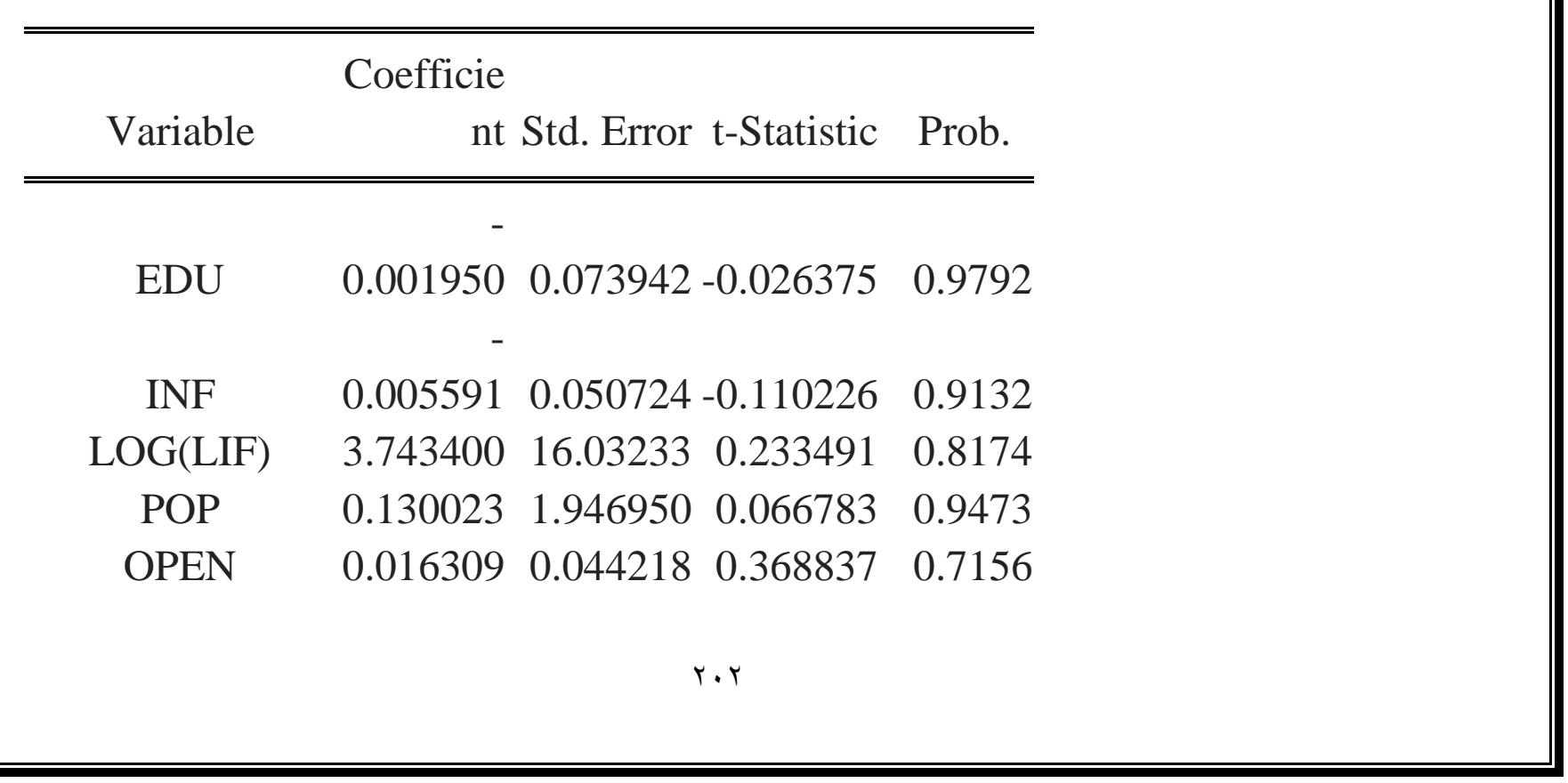




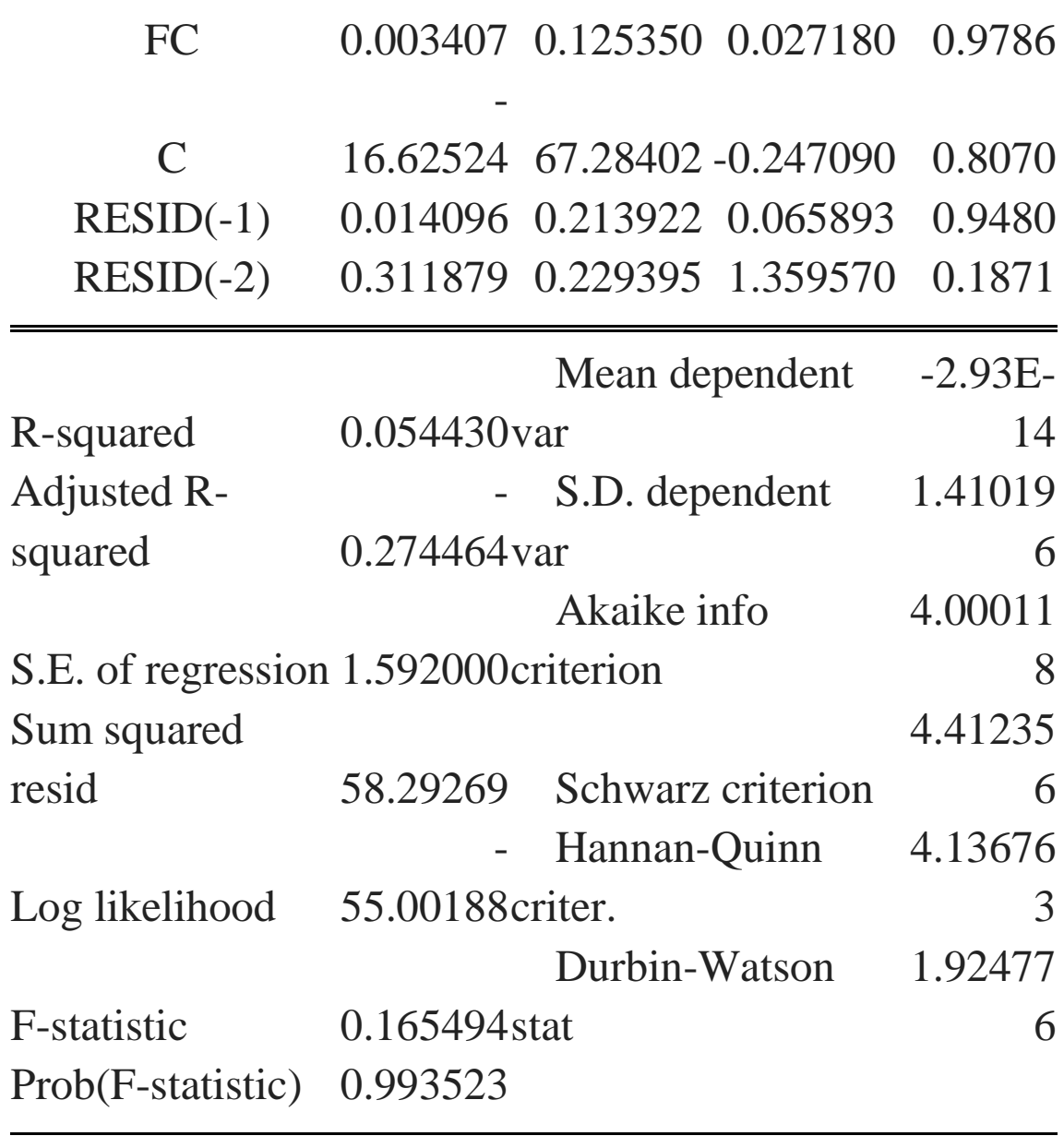

Heteroskedasticity Test: Breusch-Pagan-Godfrey

\begin{tabular}{llll}
\hline \hline F-statistic & 0.987819 & $\begin{array}{l}\text { Prob. F(6,25) } \\
\text { Prob. Chi- }\end{array}$ & 0.4545 \\
& &
\end{tabular}

Obs*R-squared 6.132561Square(6) 0.4085

Scaled explained Prob. Chi-

SS 2.899311Square(6) 0.8214

Test Equation:

Dependent Variable: RESID^2

Method: Least Squares

Date: 07/22/20 Time: 14:06

Sample: 19802017

Included observations: 32

\section{Coefficie}

Variable nt Std. Error t-Statistic Prob. 


\begin{tabular}{|c|c|c|}
\hline $\mathrm{C}$ & $\begin{array}{lll}162.5327 & 101.3162 & 1.604213\end{array}$ & 0.1212 \\
\hline EDU & $\begin{array}{llll}0.141337 & 0.113051 & 1.250201\end{array}$ & 0.2228 \\
\hline INF & $\begin{array}{lll}0.005743 & 0.077027 & 0.074565\end{array}$ & 0.9412 \\
\hline LOG(LIF) & $40.8456624 .19348-1.688292$ & 0.1038 \\
\hline POP & $\begin{array}{llll}0.852706 & 2.976961 & 0.286435\end{array}$ & 0.7769 \\
\hline OPEN & $\begin{array}{ccc}0.013298 & 0.065113 & 0.204222 \\
- & & \end{array}$ & 0.8398 \\
\hline \multirow[t]{2}{*}{ FC } & $0.080435 \quad 0.191137-0.420825$ & 0.6775 \\
\hline & Mean dependent & 1.92650 \\
\hline \multirow{4}{*}{$\begin{array}{l}\text { R-squared } \\
\text { Adjusted R- } \\
\text { squared }\end{array}$} & 0.191643 var & 6 \\
\hline & - S.D. dependent & 2.43621 \\
\hline & 0.002363 var & 7 \\
\hline & Akaike info & 4.81177 \\
\hline \multicolumn{2}{|c|}{ S.E. of regression 2.439094 criterion } & 0 \\
\hline \multicolumn{2}{|l|}{ Sum squared } & 5.13240 \\
\hline \multirow[t]{2}{*}{ resid } & 148.7295 Schwarz criterion & 0 \\
\hline & - Hannan-Quinn & 4.91805 \\
\hline \multirow[t]{2}{*}{ Log likelihood } & 69.98832 criter. & 0 \\
\hline & Durbin-Watson & 2.47309 \\
\hline F-statistic & 0.987819 stat & 8 \\
\hline Prob(F-statistic) & 0.454548 & \\
\hline
\end{tabular}

VAR Residual Normality Tests

Orthogonalization: Cholesky (Lutkepohl)

Null Hypothesis: residuals are multivariate

normal

Date: 07/22/20 Time: 14:10

Sample: 19802018

Included observations: 30

\begin{tabular}{ccccc}
\hline $\begin{array}{c}\text { Componen } \\
\mathrm{t}\end{array}$ & Skewness & Chi-sq & Df & Prob. \\
\hline \hline 1 & 0.124610 & 0.077639 & 1 & 0.7805 \\
\hline \hline
\end{tabular}




\begin{tabular}{ccccc} 
Joint & & 0.077639 & 1 & 0.7805 \\
\hline \hline $\begin{array}{c}\text { Componen } \\
\mathrm{t}\end{array}$ & Kurtosis & Chi-sq & Df & Prob. \\
\hline \hline 1 & 1.313550 & 3.555141 & 1 & 0.0594 \\
\hline \hline Joint & & 3.555141 & 1 & 0.0594 \\
\hline \hline
\end{tabular}

\begin{tabular}{cccc}
\hline \hline $\begin{array}{c}\text { Componen } \\
\mathrm{t}\end{array}$ & $\begin{array}{c}\text { Jarque- } \\
\text { Bera }\end{array}$ & df & Prob. \\
\hline \hline 1 & 3.632780 & 2 & 0.1626 \\
\hline \hline Joint & 3.632780 & 2 & 0.1626 \\
\hline \hline
\end{tabular}

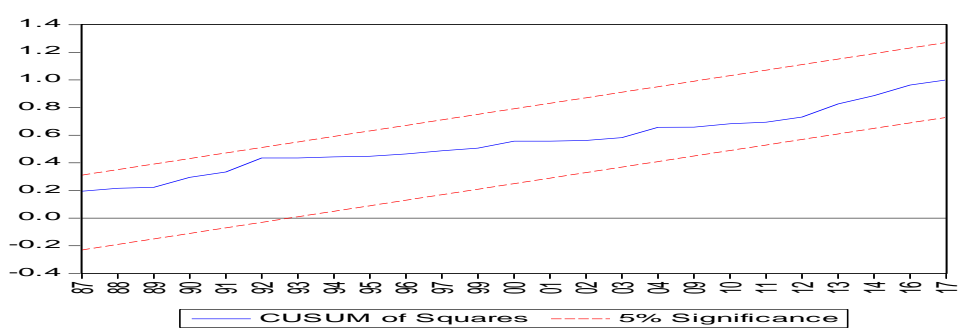

VAR Residual Serial Correlation LM Tests

Null Hypothesis: no serial correlation at lag order $h$

Date: 07/22/20 Time: 14:11

Sample: 1980

2018

Included observations: 30

\begin{tabular}{cll}
\hline \hline Lags & LM-Stat & Prob \\
\hline \hline 1 & 0.000206 & 0.9885 \\
2 & 0.717745 & 0.3969 \\
3 & 0.000537 & 0.9815 \\
4 & 0.030346 & 0.8617 \\
5 & 0.189747 & 0.6631 \\
6 & 0.071044 & 0.7898 \\
7 & 1.062322 & 0.3027 \\
8 & 0.358832 & 0.5492 \\
9 & 0.192919 & 0.6605 \\
& & r.o
\end{tabular}



$10 \quad 0.128462$
0.7200
$11 \quad 0.063529$
0.8010
$12 \quad 0.542658$
0.4613

Probs from chi-square with $1 \mathrm{df}$.

\section{References:}

Boumaraf E, Amari A. 2013 For sustainable health development in Algeria. Research published at https://revues.univ-ouargla.dz/index. php/numero-07-2009/690--05-06-15-46-30 .

Mazrak S, Mebrouk A-B. 2012/2013 The role of quality of health services in sustainable human development, a case study of the public hospital institution, Muhammad bin Al-Siddiq bin Yahya (Jijel). Master Thesis in Economic and Management Sciences, Faculty of Economics and Management Sciences. University of Setif, Algeria.

Al-Fatih M. M. The economics of health care services in developing countries and their implications for development. Amarabac Magazine. Published by the American Academy of Science and Technology. WWW.amarabac.com. Fourth volume. Issue Ten (2013) pp. 121138.

Mukhtar R, 2014.Health and disease and its relationship to the cultural coordination of society from the perspective of medical anthropology. Journal of Human and Social Sciences - Issue 15 / June pp. 173: 186.

Jennifer R \& others. Are better health outcomes linked to social hypocrisy? Social spending and population health measures in a cross-national pilot analysis. Translated and published research at https://www.rand

Anna S, F. 2017 A purple economy: The Case for placing the economics of care at the heart of sustainable development, www.neweconomics.org

Santosh K, T. Miss Snehlata Jaiswal. 2018. Purple Economy Component of a Sustainable Economy in India. IOSR Journal of Business and Management (IOSR-JBM) e-ISSN: 2278487X, p-ISSN: 2319-7668. Volume 20, Issue 12. Ver. III (December.), PP 47-50 www.iosrjournals.org.

Jabouri, A, A. 2019Sustainable health development: challenges and future trends, an environmental, economic, and social approach. Journal of Human Resources Development for Studies and Research - Issue Six - October .

Seo Siegel \& others. 2016. Toward Healthy Communities: Developing Strategies to Improve Population Health. Report of the WISH Forum on Healthy Communities. p. 7. 
Richardson, William C. 2016. crossing the Quality chasm: A new Health system for the 21st century. 20 Novamber.

https://www.who.int

The World Bank - 2018. Cabinet Presidency - Egyptian Ministry of Health. Summary of the project to develop the health care system in Egypt. Cairo.

The World Bank - 2018. Cabinet Presidency - Egyptian Ministry of Health. Summary of the project to develop the health care system in Egypt. Cairo.

Presidency of the Council of Ministers 2020- Egyptian Ministry of Health and Population. An internal report on the extent of achievement of health projects in Egypt (unpublished report). Cairo. May.

Confederation, UNESCO -, 2015. Organization for Economic Cooperation and Development - Organization of States. Way back Machine. September 23

Robiaat. Abdallah. 2020.https://www.aleqt.com/2020/03/06/article_1774821.html. March 6 ،

Hosgarhar, Utah. UNESCO 2017.- Mission - Multiple Voices One World .

Introduction to Health and Nutrition 2018., www.repository.taibahu.edu.sa. October 12, 